\title{
Respiratory health of workers exposed to metal dusts and foundry fumes in a copper refinery
}

\author{
Gaston Ostiguy, Claude Vaillancourt, Raymond Bégin
}

Hopital MaisonneuveRosemont G Ostiguy

CLSC Octave Roussin, Montréal C Vaillancourt CHU Sherbrooke, Québec, Canada R Bégin

Correspondence to: Dr Raymond Bégin, Service de pneumologie, CHUS, 300112 iéme avenue Nord, Sherbrooke, Quebec, Canada J1H $5 \mathrm{~N} 4$.

Accepted 28 October 1994

\begin{abstract}
Objectives-To assess airflow limitation in workers exposed long term to metal dust, the prevalence of pleural plaques in those workers exposed in the past to asbestos, the influence of pleural plaques on lung function, and the possible association with airway disease caused by asbestos.
\end{abstract}

Methods-A cross sectional and longitudinal (seven year) survey of 494 long term (mean (SEM) 21(1) years) workers in a copper refinery was carried out from medical questionnaires, chest radiographs, and forced spirometry.

Results-The prevalence of lifetime nonsmokers was $19 \%$, current smokers $39 \%$, and ex-smokers $42 \%$. The prevalence of chronic obstructive pulmonary diseases (COPD) (forced expiratory volume in one second $\left(\mathrm{FEV}_{1}\right)<\mathbf{8 0} \%$ predicted) was $5 \%$, small airway dysfunction (SAD) (maximal mid-expiratory flow (MMEF) $<60 \%$ predicted) was $7 \%$, and this did not differ from the control population. The COPD and SAD were associated with cumulative smoking index but not with the cumulative work years at the plant or with any type of work at the plant. The mean (SEM) reduction of $\mathrm{FEV}_{1}$ was 20(7) $\mathrm{ml}$ in non-smokers, 26(4) $\mathrm{ml}$ in smokers, and 26(5) $\mathrm{ml}$ in exsmokers $(P>0.05)$. In the smokers and ex-smokers with COPD, the loss of FEV was 53(10) $(P<0.02)$. The prevalence of pleural plaques was $11 \%(P<0.0001)$; pleural plaques were found in older workers with known exposure to asbestos. The pleural plaques were circumscribed and associated with a non-significant $196 \mathrm{ml}$ reduction in forced vital capacity (FVC) and non-significant reduction of FVC over time. The pleural plaques were not associated with COPD or SAD. The cumulative smoking index obtained by a

FVC significantly, and exposure to asbestos dust that produced pleural plaques does not necessarily produce airway dysfunction.

(Occup Environ Med 1995;52:204-210)

Keywords: airflow limitation; pleural plaques; copper refinery

Exposures to workplace pollutants such as coal, silica, asbestos, and other mineral dusts, organic dusts, sulphur dioxide $\left(\mathrm{SO}_{2}\right)$, oxides of nitrogen, along with other gas and fume contaminants have been associated with work related respiratory diseases and disabilities.

In recent years, several reports ${ }^{1-20}$ have found associations between work in dusty environments and chronic obstructive pulmonary disease (COPD) through community based studies, cross sectional and longitudinal studies, pathology studies, and cohort mortality studies as reviewed by Becklake. ${ }^{1}$ Therefore, industrial air pollutants are suspected of being "may be, but not necessarily, implicated in the genesis of COPD".'

In this paper, we report on a cross sectional and longitudinal (seven years) respiratory survey of a population of 494 long term workers in a copper refinery who were exposed to metal dusts, gases, and foundry fumes for over 20 years on average. The specific questions considered in this study were: (a) the prevalence of COPD and its association with work, the rate of fall in airflow in the workers with or without COPD; (b) the prevalence of pleural plaques, their association with work, their effect on lung function, their association with COPD or small airway disease (SAD); and (c) the correlation between cumulative smoking index obtained by a technician at the plant and that of a consultant in the hospital clinic. technician did not differ from that by a chest physician.

Conclusions-Despite exposures to asbestos that produced pleural plaques and exposures to metal dusts and foundry fumes the long term workers of this plant did not have excessive prevalence of COPD or SAD. The data suggest that low level long term exposure to metal dusts, gases, and foundry fumes do not necessarily cause respiratory dysfunction, circumscribed pleural plaques with low grades of width and extent do not reduce
Materials and methods

POPULATION STUDIED AND SURVEY PROCEDURES

The workers studied in this investigation were all employees of a Montréal copper refinery in operation since 1910 . The plant had been the site of a few cases of occupational respiratory diseases (one mesothelioma, two pleural effusions, and one asbestosis). In the late 1970 s these cases prompted a programme of occupational health and industrial hygiene that permitted the present study. 
Table 1 Anthropometric and clinical data

\begin{tabular}{|c|c|c|c|c|}
\hline & \multicolumn{2}{|c|}{ Total study group $(n=494)$} & \multicolumn{2}{|l|}{$\geqslant 50 y(n=208)$} \\
\hline & Mean (SEM) & Range & Mean (SEM) & Range \\
\hline $\begin{array}{l}\text { Age } \\
\text { Height (cm) } \\
\text { Weight }(\mathrm{kg}) \\
\text { BMI }\left(\mathrm{kg} / \mathrm{m}^{2}\right) \\
\text { Time at plant (y) } \\
\text { Smoking index (pack-y): } \\
\text { Non-smokers }\end{array}$ & $\begin{array}{c}46 \cdot 6(0 \cdot 5) \\
174(0 \cdot 3) \\
81 \cdot 4(0 \cdot 6) \\
26 \cdot 8(0 \cdot 2) \\
20 \cdot 6(0 \cdot 5) \\
20 \cdot 9(0 \cdot 8) \\
0\end{array}$ & $\begin{array}{c}19-76 \\
152-193 \\
46-126 \\
15 \cdot 9-39 \cdot 4 \\
1-48 \\
0-150\end{array}$ & $\begin{array}{c}58 \cdot 7(0 \cdot 4) \\
173(0 \cdot 5) \\
82 \cdot 0(0 \cdot 9) \\
27 \cdot 3(0 \cdot 2) \\
28 \cdot 5(0 \cdot 5) \\
29 \cdot 1(0 \cdot 8)\end{array}$ & $\begin{array}{c}50-76 \\
152-193 \\
55-126 \\
19-39 \cdot 4 \\
11-48 \\
0-150\end{array}$ \\
\hline $\begin{array}{l}\text { Smokers } \\
\text { Ex-smokers } \\
\text { FVC (1) } \\
\text { FEV }(1 / s) \\
\text { FEV } 1 / \text { FVC }(\%) \\
\text { MMEF }(1 / s)\end{array}$ & $\begin{array}{c}28 \cdot 7(1 \cdot 1) \\
23(1 \cdot 3) \\
4 \cdot 93(0 \cdot 046) \\
4 \cdot 15(0 \cdot 043) \\
83 \cdot 9(0 \cdot 3) \\
4 \cdot 69(0 \cdot 75)\end{array}$ & $\begin{array}{l}1-90 \\
1-150 \\
1 \cdot 68-8 \cdot 44 \\
0 \cdot 89-7 \cdot 27 \\
35-99 \\
0 \cdot 33-9 \cdot 62\end{array}$ & $\begin{array}{c}39.5(1.8) \\
30.2(1.9) \\
4.23(0.055) \\
3.52(0.054) \\
83.0(0.6) \\
3.99(0.08)\end{array}$ & $\begin{array}{l}9-90 \\
1-150 \\
1 \cdot 68-6 \cdot 9 \\
0 \cdot 89-6 \cdot 35 \\
35-99 \\
0 \cdot 39-9 \cdot 14\end{array}$ \\
\hline
\end{tabular}

Smokers ( $n=194$ in total study group, $n=69$ in $\geqslant 50$ group); non-smokers = never smokers $(n=94$ in total study group, $n=29$ in $\geqslant 50$ group); ex-smokers = subjects that stopped smoking for one year before 1991 ( $n=206$ in total study group and $n=110$ in $\geqslant 50$ group).

The plant is a metal refinery that receives its raw materials largely as plates of pure $(>99 \cdot 3 \%)$ copper provided by Canadian smelters or used copper scrap from the recycling companies. The plant purifies the copper to $>99.9 \%$ through electrolytic refining of the raw materials, extracting among other residuals, silver, gold, selenium, and palladium on an industrial basis. These residuals are further purified in foundry operations. The metal dusts of copper, silver, selenium, lead, arsenic, and other trace metals and mild acid mists are found in the work environment of the plant. Also, asbestos dust had been a contaminant of the workplace, used in the insulation of the foundry furnaces and related equipment. Asbestos has been gradually removed from the plant over the past 10 years and replaced by other insulation materials. Periodic air sampling and analyses done over the past 15 years documented that the threshold limit values (TLVs) for these contaminants have been respected and the total dust measures were below the $5 \mathrm{mg} / \mathrm{m}^{3}$ TLV.

The 494 workers surveyed were all employees of the plant at the time of the cross sectional survey of 1991 and $396(80 \%)$ of them were also in the survey of 1983-4. This was used as the first data point in the longitudinal study, which also included measurements of forced spirometry in 1985-6 and 1988-9, all done by the same technician and with the same equipment. All employees surveyed except one were men. Table 1 shows their anthropometric data, employment experience, smoking habits, and absolute lung function. The complete workforce of 494 workers at the plant was studied as one group and 208 workers of 50 and over were another group. The $\geqslant 50$ subset was studied to exclude the workers with less work years at the plant (the least likely to have abnormalities) and to look specifically at the older age group, in which abnormalities are most likely to be found. This group constitutes an age limited sample of the population of interest for comparative studies. The longitudinal survey included the 396 workers with measurements at the 1983-4 and 1991 surveys.

Also, case-control analyses of COPD,
Table 2 Prevalence of airflow limitation

\begin{tabular}{|c|c|c|c|}
\hline Group & $\begin{array}{l}\text { Subjects } \\
n\end{array}$ & $\begin{array}{l}C O P D \\
n(\%)\end{array}$ & $\begin{array}{l}S A D \\
n(\%)\end{array}$ \\
\hline $\begin{array}{l}\text { Total study group: } \\
\text { Non-smokers } \\
\text { Smokers } \\
\text { Ex-smokers } \\
\geqslant 50 \text { y: } \\
\text { Non-smokers } \\
\text { Smokers } \\
\text { Ex-smokers }\end{array}$ & $\begin{array}{r}494 \\
94 \\
194 \\
206 \\
208 \\
29 \\
69 \\
110\end{array}$ & $\begin{array}{c}26(5 \cdot 26) \\
2(2) \\
14(7 \cdot 2) \\
10(4 \cdot 9) \\
20(9 \cdot 6) \\
2(6 \cdot 9) \\
9(13) \\
9(8 \cdot 2)\end{array}$ & $\begin{array}{c}73(14 \cdot 8) \\
6(6 \cdot 4) \\
45(23 \cdot 2) \\
22(10 \cdot 7) \\
44(21 \cdot 2) \\
2(6 \cdot 9) \\
25(36 \cdot 2) \\
17(15 \cdot 5)\end{array}$ \\
\hline
\end{tabular}

$\mathrm{SAD}$, and pleural plaques were performed within the study population..$^{21}$ For workers of age $\geqslant 45$ no differences were found in age, height, weight, and body mass index (BMI) between workers with or without COPD, SAD, or pleural plaques. Thus all workers in this age category but without the disease under study were used as controls. The ratios of cases to controls were 1:10 for COPD and $\mathrm{SAD}$ and $1: 4.57$ for pleural plaques. For workers < 45, age matched (within one year) controls were selected: 10 for each case of COPD or SAD, and four or five for each case of pleural plaques.

The work history was obtained from the company records, an American Thoracic Society (ATS) questionnaire ${ }^{22}$ was obtained by the plant health technician, forced spirometry was obtained by applying the ATS standards $^{23}$ with a Collins spirometer model No 6031 interfaced with an Apple IIe computer (Apple Computers, Cupertino, CA). The spirometric variables generated were forced vital capacity (FVC), forced expiratory volume in one second $\left(\mathrm{FEV}_{1}\right)$, and maximal midexpiratory volume (MMEF). The spirometric data were obtained in absolute values and as a percentage of predicted values with the Quanjer prediction formulas. ${ }^{24}$ Spirometric surveys of the plant workers were carried out in 1983-4, 1988-9, and 1991 with the same equipment and by the same technician. A few workers $(<1 \%)$ who did not meet the repeatability criteria of spirometry were excluded. The criterion for COPD was an $\mathrm{FEV}_{1}<80 \%$ predicted (combination of that and a $\mathrm{FEV}_{1} / \mathrm{FVC}<90 \%$ identified the same cases as COPD). For SAD, the criteria were the commonly applied MMEF $<60 \%$ or $<75 \%$ predicted as specified in the results section. The chest radiographs were carried out in 1991 with high $\mathrm{kV}$ in the posteroanterior projection alone, and in posteroanterior and lateral projection at maximal inspiration. The films were graded by two experienced readers (members of the Canadian Pneumoconioses Reading Panel) according to the International Labour Organisation (ILO) 1980 classification. ${ }^{25}$ Radiographs were read independently, without information on asbestos exposure, and divergences between readers were settled by joint readings, after initial independent readings.

Pleural changes were classified in terms of site, width, and extent according to the ILO classification. For each of the six sites of pleural changes (chest walls, diaphragms, and 
Table 3 Analyses of variance and regression analysis for COPD and SAD (case-control)

\begin{tabular}{|c|c|c|c|c|c|c|}
\hline & \multicolumn{6}{|l|}{$C O P D$} \\
\hline & \multicolumn{3}{|l|}{ Analyses of variance } & \multicolumn{3}{|c|}{ Logistic regression analysis } \\
\hline & $\begin{array}{l}\text { Absent }(n=280) \\
\text { mean }(S E M)\end{array}$ & $\begin{array}{l}\text { Present }(n=26) \\
\text { mean }(S E M)\end{array}$ & Pvalue & Coefficient (SEM) & $\chi^{2}$ & P value \\
\hline $\begin{array}{l}\text { Smoking index } \\
\text { Work-y } \\
\text { Loss of FEV }\end{array}$ & $\begin{array}{l}26 \cdot 2(1 \cdot 2) \\
25 \cdot 9(1) \\
46(3)\end{array}$ & $\begin{array}{l}34 \cdot 1(3 \cdot 3) \\
29 \cdot 0(2) \\
70(11)\end{array}$ & $\begin{array}{l}0.047 \\
\text { NS } \\
0.037\end{array}$ & $\begin{array}{l}0.002(0.0001) \\
0.002(0.002) \\
0.027(0.01)\end{array}$ & $\begin{array}{r}22 \cdot 47 \\
0.90 \\
4 \cdot 78\end{array}$ & $\begin{array}{l}<0.0001 \\
\text { NS } \\
0.03\end{array}$ \\
\hline
\end{tabular}

*In the case-control 1983-4 and 1991 surveys, some of the cases and controls were not in both surveys due to absenteeism, temporary reduction of workforce at time of surveys, or poor technical repeatability of spirometry; for the COPD study control group $n=255$ and case group $n=23$; for the SAD study control group $\mathrm{n}=222$ and case group $\mathrm{n}=54$. $\chi^{2}=$ likelihood ratio test.

costophrenic angles) a width category $a, b$, or $c$ and an extent score 1,2 , or 3 were given. A simple total score of pleural changes was developed to scale the asbestos pleural abnormalities as follows: each change in diaphragm and costophrenic angle was scored as 1 (maximum of 4), pleural plaques "face on" were scored as 1; the circumscribed pleural plaques classified as $a 1, a 2, b 1$ were scored as 1 , the $a 3, b 2, c 1$ as 2 and the $b 3, c 2$, and $c 3$ as 3 for each side of the thorax. The pleural changes classified as diffuse were scored at two times the score of circumscribed pleural changes for the same type of ILO classification as abovethat is, a diffuse pleural change of b2 ILO classification would be scored as 4 when diffuse. With this scale, our subjects had scores of pleural disease that varied between 0 and 16.

\section{STATISTICAL ANALYSES}

All data were transferred to a data base for statistical analyses. All results are expressed as mean (SEM). The data were analysed with Statview 4.01, SuperAnova (Brainpower, Calabasas, CA), and SPSS 4.0 (SPSS, Chicago, ILL). Contingency tables with the $\chi^{2}$ Mantel-Haenszel test were used to compare prevalence data, analyses of variance (ANOVA) with post hoc Scheffe's test to compare group data, multiple analyses of variance (MANOVA) to study the relations of spirometry values with pleural plaques and age, body mass index (BMI), smoking index, and years at the plant, logistic regression analyses for the relation of pleural plaques (presence or absence) and worksites, and multiple variate regression analysis for the relation between airflow limitation or pleural plaque grade and years at the various worksites. Significance was at the $P<0.05$ level.

\section{Results}

AIRFLOW LIMITATION

In the total population of the 494 workers surveyed, the prevalence of COPD was $5.26 \%, 2 \%$ in non-smokers, $4.9 \%$ in exsmokers, and $7 \cdot 2 \%$ in current smokers (table 2). In the subsets of older workers, the prevalence was higher, reaching $13 \%$ in the current smokers of $\geqslant 50$. These results were in the range of a local control study and of other north American and European studies. ${ }^{826-30}$ The prevalence of COPD was significantly higher in the smokers and exsmokers than in the non-smokers $\left(\chi^{2}=3.77\right.$, $P=0.05$, relative risk $=5.8(0.8-44)$.

The prevalence of SAD was also studied in the total population of the plant and in the subset of older workers. Table 2 shows the data with the $<75 \%$ predicted criterion for the definition of SAD and comparison with the general population of Michigan gathered in the data of Miller et al. ${ }^{28}$ The prevalence of $\mathrm{SAD}$ is generally low in our workers and significantly lower than in the reference material by Miller et $a l .^{28}$ This is most likely a healthy worker effect as our study included only active workers. Similar findings were obtained with $<60 \%$ predicted or $95 \%$ confidence interval criteria.

Analysis of airflow dysfunction in relation to smoking index (table 3), showed significantly higher indices of smoking in the people with COPD or SAD than in those without. The annual loss of $\mathrm{FEV}_{1}$ was found to be significantly higher in the people with COPD, twice the level of people without COPD. Of the 24 people with COPD 22 were either current or ex-smokers. Smoking index was

Table 4 Radiograph readings of the 1991 survey on the basis of the ILO classification ${ }^{25}$

\begin{tabular}{|c|c|c|}
\hline & Total & $n(\%)^{*}$ \\
\hline $\begin{array}{l}\text { Any pleural thickening } \\
\geqslant 50 \text { y } \\
\text { Case-control (ratio) } \\
\text { Chest wall, circumscribed: } \\
\text { Plaques: }\end{array}$ & $\begin{array}{l}494 \\
208\end{array}$ & $\begin{array}{c}54(11) \\
44(21) \\
54-247(1-4 \cdot 57) \\
54(100)\end{array}$ \\
\hline $\begin{array}{l}\text { Bilateral: } \\
\text { Width: }\end{array}$ & & $23(43)$ \\
\hline $\begin{array}{l}\leqslant 5 \mathrm{~mm} \\
5-10 \mathrm{~mm} \\
10 \mathrm{~mm}\end{array}$ & & $\begin{array}{c}47(84) \\
19(34) \\
5(9)\end{array}$ \\
\hline Extent: & & \\
\hline $\begin{array}{l}\leqslant 1 / 4 \text { of chest wall } \\
>1 / 4 \text { and }<1 / 2 \\
>1 / 2\end{array}$ & & $\begin{array}{l}47(66) \\
11(16) \\
13(18)\end{array}$ \\
\hline Face on & & $21(39)$ \\
\hline Chest wall diffuse & & $0(0)$ \\
\hline $\begin{array}{l}\text { Diaphragmatic plaque: } \\
\text { Unilateral }\end{array}$ & & $14(26)$ \\
\hline Bilateral & & $3(21)$ \\
\hline Costodiaphragmatic angle: & & $4(7)$ \\
\hline Unilateral & & $3(75)$ \\
\hline Bilateral & & $1(25)$ \\
\hline Calcified plaques & & $5(9)$ \\
\hline Parenchymal small opacities: & & \\
\hline Profusion $0 / 0$ & 494 & $477(96)$ \\
\hline $0 / 1$ & & $5(1)$ \\
\hline $1 / 0$ & & $8(1 \cdot 6)$ \\
\hline $1 / 1+$ & & $4(0 \cdot 8)$ \\
\hline
\end{tabular}

${ }^{\star}$ Refers to pleural thickening on either side and to maximum recorded width or extent. Interstitial lung disease was excluded in all but two cases by complementary clinical investigation ${ }^{39}$ that included detailed physical examination, complete lung function tests, and thin section $\mathrm{CT}$. 


\begin{tabular}{|c|c|c|c|c|c|}
\hline \multicolumn{6}{|l|}{$S A D$} \\
\hline \multicolumn{3}{|c|}{ Analyses of variance } & \multicolumn{3}{|c|}{ Logistic regression analysis } \\
\hline $\begin{array}{l}\text { Absent }(n=244) \\
\text { mean }(S E M)\end{array}$ & $\begin{array}{l}\text { Present }(n=57) \\
\text { mean }(S E M)\end{array}$ & P value & Coefficient (SEM) & $\chi^{2}$ & Pvalue \\
\hline $\begin{array}{l}25 \cdot 1(1 \cdot 3) \\
26 \cdot 1(1 \cdot 0) \\
45(3)\end{array}$ & $\begin{array}{l}35 \cdot 1(1 \cdot 9) \\
28 \cdot 0(1 \cdot 9) \\
81(10)\end{array}$ & $\begin{array}{l}0.004 \\
\text { NS } \\
0.001\end{array}$ & $\begin{array}{l}0.011(0.001) \\
0.004(0.003) \\
2.35(0.44)\end{array}$ & $\begin{array}{r}11 \cdot 13 \\
1.93 \\
29.09\end{array}$ & $\begin{array}{l}0.001 \\
\text { NS } \\
<0.0001\end{array}$ \\
\hline
\end{tabular}

significantly and consistently associated with COPD within the population of this study.

There was, however, no significant association of airflow dysfunction with the number of years worked at the plant (table 3). Logistic regression analyses (not shown) for work by department in relation to COPD found only foundry work as a potential contributor to airflow dysfunction. In the case-control study, however, foundry work was not a significant contributor to COPD. Thus, no work site contributed consistently to the genesis of airflow dysfunction in the workers of this plant.

\section{PLEURAL PLAQUES}

In the total population of the 494 workers surveyed in the plant, the prevalence of pleural plaques was $11 \%$ or 54 cases. All pleural thickenings were classified according to the ILO $^{25}$ as costophrenic angle obliteration or pleural thickening of the chest wall or diaphragm (table 4). All plaques were circumscribed and of low grade; all thickenings were $<30 \%$ maximum grade on the 0 to 16 scale. Nine per cent of the cases had calcified plaques. All readings of lung parenchyma were in category 0 (no pneumoconiosis).

Analyses of factors contributing to the prevalence of pleural plaques in the total population of the plant (table 5) showed that plaques were present mostly in the older workers, with higher BMI, smoking index, and work-years at the plant. Further logistic and multiple variate regression analyses in the case-control study of pleural plaques (not shown) did not identify age, BMI, work-years, asbestos exposed work-years, or specific worksites as strongly associated with presence, absence, or score of pleural plaques. Thus the increased prevalence of pleural plaques in the plant is largely found in older workers of the plant, employed at a time when asbestos exposure at the plant was well recognised. No specific site of work was associated with pleural plaques.

To assess the potential effect of pleural plaques that had low grades of width or extent on spirometric data, we did multiple analyses of variance on the spirometric data in relation to pleural plaques (presence or absence and score), smoking index, and BMI (table 6). We consistently found that pleural plaques in our population did not significantly affect the spirometric data that were otherwise significantly associated with the smoking index and the BMI. The MMEF data were less significantly associated with BMI than the other two spirometric variables, FVC and $\mathrm{FEV}_{1}$. Analyses of variance were also done between the subsets with or without pleural plaques for the spirometric data (table 7); the FVC of cases with pleural plaques was $196 \mathrm{ml}$ or $2.4 \%$ predicted FVC lower than controls without pleural plaques $(P>0.05)$. The longitudinal analyses of spirometric variables (table 7) showed that the workers with pleural plaques with low grades of width or extent were losing FVC at a rate not significantly different from their colleagues without pleural plaques.

Finally, we analysed the data to consider a potential association of COPD or SAD and pleural plaques and found no significant association.

\section{INTERSTITIAL LUNG DISEASE}

The clinical investigation of all cases with pleural or pulmonary changes on the 1991 radiograph survey (table 4) showed the absence of interstitial lung disease in all but two cases.

\section{CUMULATIVE SMOKING INDEX}

The correlation between cumulative smoking index obtained by a technician at the plant and that of a consultant in the hospital clinic was analysed in 51 cases where data were collected independently. The results of the analyses clearly show no difference (difference $=1 \cdot 59, t=0 \cdot 75, \mathrm{NS})$.

\section{Discussion}

This study was initiated to allay the concern of workers of the plant, after the recognition that several workers presented with diseases of an occupational nature. Given the known exposures in the plant to contaminants such as metal dusts, asbestos fibres, other dusts, and foundry fumes, we looked for chronic

Table 5 Analysis of variance for pleural plaques by factors

\begin{tabular}{|c|c|c|c|c|c|c|c|c|}
\hline & \multicolumn{4}{|l|}{ Total study group } & \multicolumn{4}{|l|}{ Case-control } \\
\hline & \multicolumn{2}{|l|}{ Pleural plaques } & \multirow[b]{2}{*}{$F$ ratio } & \multirow[b]{2}{*}{ Pvalue } & \multicolumn{2}{|l|}{ Pleural plaques } & \multirow[b]{2}{*}{$F$ ratio } & \multirow[b]{2}{*}{$P$ value } \\
\hline & $\begin{array}{l}\text { Present }(n=54) \\
\text { mean }(S E M)\end{array}$ & $\begin{array}{l}\text { Absent }(n=440) \\
\text { mean }(S E M)\end{array}$ & & & $\begin{array}{l}\text { Present }(n=54) \\
\text { mean }(S E M)\end{array}$ & $\begin{array}{l}\text { Absent }(n=247) \\
\text { mean }(S E M)\end{array}$ & & \\
\hline $\begin{array}{l}\text { Age (y) } \\
\text { BMI (kg/m²) } \\
\text { Smoking index } \\
\text { Work (pack-y) }\end{array}$ & $\begin{array}{l}55(1 \cdot 1) \\
28 \cdot 1(0 \cdot 5) \\
27 \cdot 4(2 \cdot 7) \\
26 \cdot 3(1 \cdot 0)\end{array}$ & $\begin{array}{l}45(0 \cdot 6) \\
26 \cdot 7(0 \cdot 2) \\
20 \cdot 0(0 \cdot 9) \\
19 \cdot 8(0 \cdot 5)\end{array}$ & $\begin{array}{r}32 \cdot 8 \\
8 \cdot 2 \\
8 \cdot 4 \\
21 \cdot 8\end{array}$ & $\begin{array}{r}<0.0001 \\
0.0043 \\
0.0038 \\
<0.0001\end{array}$ & $\begin{array}{l}56(1 \cdot 1) \\
27 \cdot 8(0 \cdot 5) \\
28 \cdot 6(2 \cdot 0) \\
26 \cdot 8(1 \cdot 0)\end{array}$ & $\begin{array}{l}54(0 \cdot 9) \\
27 \cdot 2(0 \cdot 2) \\
26 \cdot 6(1 \cdot 2) \\
25 \cdot 7(0 \cdot 5)\end{array}$ & $\begin{array}{l}2.4 \\
1.5 \\
0.46 \\
0.79\end{array}$ & $\begin{array}{l}\text { NS } \\
\text { NS } \\
\text { NS } \\
\text { NS }\end{array}$ \\
\hline
\end{tabular}

$F$ ratio $=F$ test with ANOVA statistics. 
Table 6 Multiple analyses of variance of spirometric data by pleural plaques and factors (case-control)

\begin{tabular}{|c|c|c|c|c|}
\hline \multirow[b]{2}{*}{ Factor } & \multicolumn{2}{|c|}{ Pleural plaques (presencelabsence) } & \multicolumn{2}{|c|}{ Pleural plaques (score) } \\
\hline & $F$ ratio & Pvalue & Fratio & P value \\
\hline \multicolumn{5}{|l|}{ FVC: } \\
\hline Plaque & $0 \cdot 32$ & NS & 0.06 & NS \\
\hline Smoking index & $18 \cdot 18$ & 0.0001 & $18 \cdot 30$ & $<0.0001$ \\
\hline BMI & 14.00 & 0.0002 & $14 \cdot 34$ & $<0.0001$ \\
\hline \multicolumn{5}{|l|}{$\mathrm{FEV}_{1}$} \\
\hline Plaque & 1.37 & NS & 0.23 & NS \\
\hline Smoking index & $24 \cdot 6$ & $<0.0001$ & $24 \cdot 69$ & $<0.0001$ \\
\hline BMI & $5 \cdot 01$ & 0.025 & $5 \cdot 34$ & 0.022 \\
\hline \multicolumn{5}{|l|}{ MMEF: } \\
\hline Plaque & $1 \cdot 35$ & NS & 0.61 & NS \\
\hline Smoking index & 23.06 & $<0.0001$ & $23 \cdot 18$ & $<0.0001$ \\
\hline BMI & 0.04 & NS & $0 \cdot 16$ & NS \\
\hline
\end{tabular}

$F$ ratio $=F$ test with MANOVA statistics

Table 7 Analyses of variance of spirometric data for pleural plaques (case-control)

\begin{tabular}{|c|c|c|c|c|}
\hline & \multicolumn{2}{|l|}{ Pleural plaques } & \multirow[b]{2}{*}{ F ratio } & \multirow[b]{2}{*}{ Pvalue } \\
\hline & $\begin{array}{l}\text { Present }(n=54) \\
\text { Mean }(\text { SEM })\end{array}$ & $\begin{array}{l}\text { Absent }(n=247) \\
\text { Mean }(S E M)\end{array}$ & & \\
\hline $\begin{array}{l}\text { FVC } \\
\text { FEV }_{1} \\
\text { MMEF }^{*}\end{array}$ & $\begin{array}{l}104(2) \\
107(2) \\
106(5)\end{array}$ & $\begin{array}{l}106(1) \\
111(1) \\
114(2)\end{array}$ & $\begin{array}{l}0.91 \\
1.24 \\
1.67\end{array}$ & $\begin{array}{l}\text { NS } \\
\text { NS } \\
\text { NS }\end{array}$ \\
\hline$(\mathrm{ml} / \mathrm{y})$ & $31(12)$ & $15(6)$ & 1.5 & NS \\
\hline
\end{tabular}

${ }^{\star}$ Between $1983-4$ and 1991 surveys; $n=51$ for presence and $n=211$ for absence of pleura plaques. $F$ ratio $=F$ test with ANOVA statistics.

airflow limitation of the respiratory system associated with work in dusty departments and disorders related to asbestos.

To consider the chronic airflow limitation of the respiratory system associated with work in dusty environments, we had the last 1991 spirometric survey of all workers of the plant for a cross sectional study and the previous 1983-4 and 1986-7 surveys permitted a longitudinal study.

The cross sectional study of the 1991 spirometric data in the population of the refinery documented a prevalence of COPD and SAD in the range of a local control population of hydroelectric line installers ${ }^{25}$ and in the range of the general population of North America. ${ }^{28}$ Both studies showed smoking habits comparable with our population in terms of smoking category (current, ex or non-smokers) and pack-years. The airflow dysfunction is clearly associated with the smoking history of the workers as determined by the cumulative smoking index and the relative risk of COPD in the smokers was found to be 5.8 times that of non-smokers. Furthermore, within the subsets of smokers and ex-smokers, those with airflow dysfunction had significantly higher smoking indices.

The loss of lung function (longitudinal study), however, was not significantly associated with smoking, but with an original airflow dysfunction (table 3 ). This observation was not surprising, as it is well known that only a subset of smokers rapidly lose their lung function. ${ }^{31-33}$

Analyses of the time spent at work in the refinery and of the occupations on the worksite in relation to airflow dysfunction did not show any significant contribution of refinery, work years, or job type. This is in line with a prospective mortality study where the overall standardised mortality ratio (SMR) for copper refinery workers was 0.97 without an excess of deaths from respiratory diseases. ${ }^{34}$ Furthermore, we are not aware of any previous study that documented excess airflow dysfunction in copper refinery workers, but we recognise that copper smelting operations may have contributed to excessive airway dysfunction in several studies ${ }^{8556}$ but not in all. ${ }^{37}$

Thus for the population of this copper refinery, both the longitudinal and cross sectional studies did not show excessive prevalence of airflow dysfunction and excessive loss of lung function over time. Given that the workers of this plant were usually not exposed to dusts above the TLVs, we suggest that the current TLVs in the plant are safe and the enforcement of TLVs effectively prevented the development of chronic airflow limitation of the respiratory system associated with work in a dusty environment.

Our data are not inconsistent with the general concept proposed by Becklake on the relation of chronic airflow limitation to work in dusty occupations. ${ }^{2}$ Our data document that long term work in the dusty environment of a copper refinery, within the TLVs, does not cause excessive prevalence of chronic airflow dysfunction. It is therefore compatible with the statement of Becklake that occupational exposures "may be, but not necessarily, implicated in the genesis of COPD". ${ }^{1}$

For asbestos related disorders, we are aware of one case of mesothelioma in this copper refinery. One man was also exposed to asbestos in an oil and gas refinery before he joined the copper refinery. On the surveys of chest radiographs of 1991, we found eight cases in the $1 / 0$ and four cases in the $\geqslant 1 / 1$ ILO categories suggestive of asbestosis ${ }^{38} 39$ and one case of asbestos pleuresy, which triggered the present work.

The prevalence of pleural plaques was $11 \%$ for the total population and $21 \%$ for the $\geqslant 50$ group. These values are clearly above those of the general population (usually $<3 \%{ }^{40}$ ) but in the range of populations of workers with known exposure to asbestos in industry. ${ }^{4146}$ Given the past use of asbestos for insulation of furnaces and pipes in the refinery, the prevalence of pleural plaques in our population is not unexpected. The pleural plaques were found mainly in the older workers, a reflection of past exposure and the time delay between exposure and recognition of plaques. The job definition of each worker did not differentiate the cases with pleural plaques from those without (table 5). Thus the excess of pleural plaques in the workers of this refinery is clear. It is present among the older workers and probably related to the past exposure to asbestos at the plant, although analysis based on work history did not confirm the relation.

The circumscribed pleural plaques of low grade width or extent in our workers have no significant influence on FVC, $\mathrm{FEV}_{1}$, or MMEF; FVC being mainly influenced by body mass and smoking whereas $\mathrm{FEV}_{1}$ and MMEF were mainly affected by smoking 
history (table 6). Overall, the presence of circumscribed pleural plaques was associated with a non-significant reduction of $<200 \mathrm{ml}$ FVC, with a normal slope of FVC decline over time (table 7). Our report is of particular interest on the functional effects of circumscribed pleural plaques, as several previous reports ${ }^{41-46}$ have suggested a restrictive effect on lung function of pleural plaques (recently reviewed ${ }^{43}$ ). These studies were on populations of subjects heavily exposed (insulators, pipe fitters, sheet metal workers, etc) with a higher prevalence of pleural plaques, and the results were in part affected by associated interstitial lung disease in some cases. In one study, when the confounding effect of interstitial lung disease was excluded, reduction of FVC was only $4 \%$ of FVC (as in this study). ${ }^{42}$ In another study the effect of pleural disease related to asbestos had a detrimental effect on lung function, most pronounced in subjects with blunting of the costophrenic angle, a marker of diffuse pleural fibrosis. ${ }^{43}$ In our study in all but two cases interstitial lung disease was excluded by the ILO reading of the chest radiograph and complementary clinical investigation, ${ }^{39}$ which included detailed physical examination, complete lung function tests, and thin section computed tomography (CT). Our investigation further establishes that isolated circumscribed pleural plaques with low grade width or extent are associated with a non-significant $196 \mathrm{ml}$ reduction of FVC $(2.4 \%$ predicted FVC) and a normal slope of decline of FVC over seven years.

Considering the question of a possible relation between exposure to asbestos and airflow dysfunction, ${ }^{47} 51$ we analysed the relation of presence or absence of pleural plaques and COPD or SAD and found no significant association. The data therefore indicate that the relatively low exposure to asbestos of our subjects with isolated circumscribed pleural plaques did not cause airflow dysfunction.

In conclusion, the data of this study of long term workers of a copper refinery suggest that: (a) low level long term exposure to metal dusts, gases, and fumes do not necessarily cause respiratory dysfunction; $(b)$ isolated circumscribed pleural plaques with low grade width or extent are associated with a nonsignificant $196 \mathrm{ml}$ reduction in FVC with a normal slope of decline of FVC over seven years; and (c) exposure to asbestos dust that produced isolated circumscribed pleural plaques does not necessarily produce airway dysfunction.

This work was supported by MRC Canada. We acknowledge the technical support of Ms Nicole Cerat.

1 Becklake MR. Chronic airflow limitation: its relationship to work in dusty occupations. Chest $1985 ; 88: 608-17$.

2 Becklake MR. Occupational exposures: evidence for a causal association with chronic obstructive pulmonary causal association with chronic obstructive
disease. Am Rev Respir Dis 1989;140:S85-91.

3 Brooks SM, Kalica AR. NHLBI workshop summary. Strategies for elucidating the relation between occupa-
tional exposures and airflow obstruction. Am Rev Respir tional exposures and

4 Kaufmann F, Drouet D, Lellough P, Brille D. Twelve years spirometric changes among Paris area workers. Int $\mathcal{F}$ Epidemiol 1979;8:201-12.
6 Kaufmann F, Drouet D, Lellouch J, Brille D. Occupational exposure and 12-year spirometric changes among Paris area workers. $\mathrm{Br} \mathcal{F}$ Ind Med 1982;39: 221-32.

7 Love RG, Miller BG. Longitudinal study of lung function in coal miners. Thorax 1982;37:193-7.

8 Manfreda J, Johnson B, Cherniack R. Respiratory abnormalities in employees of hard rock mining industry. $\mathrm{Am}$ Rev Respir Dis 1982;126:629-34.

9 Wiles FJ, Faure MH. Chronic obstructive lung disease in gold miners. In: Walton WH, McGovern B, eds. Inhaled particles:IV. Oxford: Pergamon Press, 1975;21:255-9.

10 Becklake MR, Du Preez L, Lutz W. Lung function in silicosis of the Witwatersrand gold mines. American silicosis of the Witwatersrand gold
Review of Tuberculosis 1958;77:400-12.

11 Becklake MR, Irving L, Kielkowski D, Webster I, De Beer M, Landau S. The predictors of emphysema in South Africa gold miners. Am Rev Respir Dis 1987;135: $1234-41$.

12 Schmidt U. Dust exposure, chronic bronchitis and emphysema. Eur F Respir Dis 1982;63(suppl 118):59-67.

13 Thériault GP, Peters JM, Fine LJ. Pulmonary function in granite shed workers of Vermont. Arch Environ Health 1974;28:18-22.

14 Theriault GP, Peters JM, Johnson WM. Pulmonary function and roentgenologic changes in granite dust exposure. Arch Environ Health 1974;28:23-7.

15 Musk AW, Peters JM, Johnson WM. Pulmonary function in granite dust exposure: a four-year follow-up. Am Rev Respir Dis 1978;115:769-76.

16 Irwig LM, Rocks P. Lung function and respiratory symptoms in silicotic and nonsilicotic gold miners. Am Rev Respir Dis 1978;117:429-35.

17 Lebowitz M, Knudson R, Burrow B. Tucson epidemiologic study of obstructive lung disease. 1. Methodology and prevalence of disease. Am $\mathcal{F}$ Epidemiol 1975;102: 137-52.

18 Lebowitz $M$. Occupational exposures in relation to symptomatology and lung function in a community population. Environ Res 1977; 44:59-67.

19 Lebowitz M. 2. Trends for cohort studies. The trends in airway obstructive disease mortality in the Tucson epidemiological study. Am Rev Respir Dis 1989;140: S $35-41$.

20 Abrahamson MJ, Wlodarczyk JH, Saunders NA, Hensley MJ. Does aluminum smelting cause lung disease? $\mathrm{Am}$ Rev Respir Dis 1989;139:1042-57.

21 Kleinbaum DG, Kupper LL, Morgenstern H. Epidemiologic research. Principles and quantitative methods. New York: Van Nostrand Reinhold, 1982.

22 Ferris BG, principal investigator. Epidemiology standardization: respiratory questionnaire. Am Rev Respir Dis 1978;118:1-120.

23 Gardner RM. ATS Statement-Snowbird workshop on standardization of spirometry. Am Rev Respir Dis 1979; 119:831-8.

24 Quanjer $\mathrm{Ph} \mathrm{H}$, ed. Standardized lung function testing. Report working party "Standardization of lung function tests", European Community for Coal and Steel. Bulletins of European Physiopathological Respiration 1983; 19(suppl 5).

25 International Labour Organisation/University of Cincinnatti. International classification of radiographs of pneumoconioses. Geneva: International Labour Office, pneumoconioses. Geneva: International Labour Office,
1980 . (Occupational safety and health series No 22.)

26 Kueppers F, Miller RD, Gordon H, Hepper NG, Offord $\mathrm{K}$. Familial prevalence of chronic obstructive pulmonary disease in a matched pair study. Am $\mathcal{F} M e d 1977 ; 63$ : 336-42.

27 Martin RR, Durant P, Ghezzo H. Studies on the health of primary aluminium workers in Quebec: airway obstructionchronic components. Montréal: Alcan Aluminium, 1986.

28 Miller A, Warshaw R, Thornton JC. Prevalence of spirometric abnormalities in a representative sample of the population of Michigan. Am f Ind Med 1991;19:473-85.

29 Dockery DW, Ware JH, Ferris BG, Glicksberg DS, Fay ME, Spiro A, Speizer FE. Distribution of forced expiratory volume in one second and forced vital capacity in healthy, white adult never-smok
Rev Respir Dis 1985;131:511-20

Rev Respir Dis 1985;131:511-20.
30 Fletcher C, Peto R. The natural history of chronic airflow obstruction. BMF 1977;1:1645-8.

31 Bates DV. Effects of smoking and environmental pollutants. In: DV Bates, ed. Respiratory function in disease. Philadelphia: WB Saunders, 1989:152-67.

32 Buist AS, Ducic S. Smoking. Evaluation of studies which have demonstrated pulmonary function changes. In: PT Macklem, S Permutt eds. The lung in the transition between health and disease. Vol 12. Lung biology in health and disease. New York: Marcel Dekker, 1979:271-86.

33 Fletcher C, Peto R, Tinker C, Speizer FE. The natural history of chronic bronchitis and emphysema. Oxford: Oxford University Press, 1976.

34 Logue IN, Koontz MD, Hattwick AW. A historical prospective mortality study of workers in copper and zinc refineries. F Occup Med 1982;24:398-408.

35 Smith TJ, Peters JM, Reading JC, Castle CH. Pulmonary impairment from chronic exposure to sulfur dioxide in a impairment from chronic exposure to sulfur

36 Lebovitz MD, Burton A, Kaltenborn W. Pulmonary function in smelter workers. 7 Occup Med 1979;21:255-9.

37 Rom WN, Wood SD, White GL, Bang KM, Reading JC. Longitudinal evaluation of pulmonary function in copper smelter workers exposed to sulfur dioxide. Am Rev Respir Dis 1986;133:830-3. 
38 Task force on occupational respiratory disease [G Ostiguy, chairman]. Health and welfare Canada. Ottawa: chairman]. Health and welfare

39 Bégin R, Ostiguy G, Filion R, Colman N, Bertrand P. Computed tomography in the early detection of asbestosis. Br F Ind Med 1993;50:689-98.

40 Hillerdal G. Pleural plaques in the general population. Ann NY Acad Sci 1991;643:430-7.

41 Schwartz DA, Fuortes LJ, Galvin JR, Burmeister LF, Schmidt LE, Leistikow N, et al. Asbestos-induced pleural fibrosis and impaired lung function. Am Rev Respir Dis 1990;141:321-6.

42 Bourbeau J, Ernst P, Chrome J, Armstrong B, Becklake $M$. The relationship between respiratory impairment and asbestos-related pleural abnormality in an active work force. Am Rev Respir Dis 1990;142:837-42.

43 Schwartz DA. Newer developments in asbestos-induced pleural disease. Chest 1991;99:191-8.

44 Kilburn KH, Warshaw RH. Abnormal lung function associated with asbestos disease of the pleura, the lung and both: a comparative analysis. Thorax $1991 ; 46: 33-8$.

45 Miller A, Bhuptani A, Sloane MF, Brown LK, Teirstein A. Cardiorespiratory responses to incremental exercise in patients with asbestos-related pleural thickening and patients with asbestos-related pleural thickening and 1993;103:1045-50.

46 Schwartz DA, Galvin JR, Yagla SJ, Speakman SB, Merchant JA, Hunninghake GW. Restrictive lung function and asbestos-induced pleural fibrosis. F Clin Invest 1993;91:2685-92.

47 Harless KW, Watanabe S, Renzetti $\mathrm{AD}$. The acute effects of chrysotile asbestos exposure on lung function. Environ Res 1978;16:360-72.

48 Bégin R, Cantin A, Berthiaume Y, Boileau R, Péloquin S, Massé S. Airway function in lifetime-nonsmoking older asbestos workers. Am $₹$ Med 1983;75:631-8.

49 Wright JL, Churg A. Morphology of small-airway lesions in patients with asbestos exposure. Hum Pathol 1984;15:68-74.

50 Kennedy SM, Wright JL, Mullen JB, Paré PD, Hogg JC. Pulmonary function and peripheral airway disease in patients with mineral dust or fume exposure. Am Rev

51 Bégin $R$, Boileau $R$, Péloquin S. Asbestos exposure, cigarette smoking, and airflow limitation in long-term Canadian chrysotile miners and millers. Am $\mathcal{F}$ Ind Med 1987;11:55-66. 